\title{
Lignocellulosic agriculture wastes as biomass feedstocks for second-generation bioethanol production: concepts and recent developments
}

\author{
Jitendra Kumar Saini • Reetu Saini • \\ Lakshmi Tewari
}

Received: 19 May 2014/Accepted: 5 August 2014/Published online: 21 August 2014

(C) The Author(s) 2014. This article is published with open access at Springerlink.com

\begin{abstract}
Production of liquid biofuels, such as bioethanol, has been advocated as a sustainable option to tackle the problems associated with rising crude oil prices, global warming and diminishing petroleum reserves. Secondgeneration bioethanol is produced from lignocellulosic feedstock by its saccharification, followed by microbial fermentation and product recovery. Agricultural residues generated as wastes during or after processing of agricultural crops are one of such renewable and lignocelluloserich biomass resources available in huge amounts for bioethanol production. These agricultural residues are converted to bioethanol in several steps which are described here. This review enlightens various steps involved in production of the second-generation bioethanol. Mechanisms and recent advances in pretreatment, cellulases production and second-generation ethanol production processes are described here.
\end{abstract}

Keywords Lignocellulose - Bioethanol - Cellulase · Agricultural wastes $\cdot$ Residues

\section{J. K. Saini · L. Tewari}

Department of Microbiology, College of Basic Sciences and Humanities, GB Pant University of Agriculture and Technology, Pantnagar, Udham Singh Nagar 263145, India

\section{R. Saini}

Department of Microbiology, M.S. Garg P.G. College, Laksar, Haridwar 247663, India

\section{Present Address:}

J. K. Saini $(\bowtie) \cdot$ R. Saini

DBT-IOC Centre for Advanced Bio-Energy Research, Research and Development Centre, Indian Oil Corporation Ltd.,

Sector-13, Faridabad 121007, Haryana, India

e-mail: me_jk@rediffmail.com

\section{Introduction}

One of the greatest challenges of twenty-first century is to meet the growing demand of energy for transportation, heating and industrial processes, and to provide raw materials for chemical industries in sustainable ways. Biofuels have emerged as an ideal option to meet these requirements in a sustainable manner. Several primary drivers underlie the increasing interests in biofuels, such as increasing uncertainty of petroleum supplies due to rising demand, decline in known reserves, and concerns over global warming and green house gas emissions associated with fossil fuels usage and this has led to various government programs promoting biofuels. Moreover, biofuels are unique among available alternative energy sources in their general compatibility with existing liquid transport fuel. The global production and use of biofuels have increased dramatically in recent years, from 18.2 billion liters in 2000 to 60.6 billion liters in 2007, with about $85 \%$ of this being bioethanol. Bioethanol is the most common and one of the practically important liquid biofuel and can be produced from a variety of cheap substrates. According to an estimate, it can reduce greenhouse gas emissions by approximately $30-85 \%$ compared to gasoline, depending on the feedstock used (Fulton et al. 2004). The USA and Brazil are currently the primary producers of fuel ethanol, producing 49.6 and $38.3 \%$ of 2007 global production, respectively (Coyle 2007). Worldwide increasing interest in the production of bioethanol is exemplified by production of 85 billion liters of bioethanol in 2011 (Singh and Bishnoi 2012; Avci et al. 2013).

The present review is a concise overview of the basic concepts and some recent advances in ethanol production with special emphasis on lignocellulosic agricultural residues/wastes and their sources, pretreatment methods,

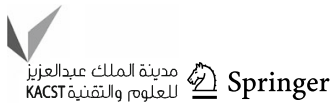


enzymatic hydrolysis and fermentation to generate bioethanol in ecologically sustainable and cost-effective manner. Some challenges still existing in economic production of second-generation bioethanol and their potential solutions are discussed in brief towards the end.

\section{Bioethanol: an eco-friendly biofuel}

Bioethanol is made biologically by fermentation of sugars derived from a variety of sources. The use of ethanol as a motor fuel began with its use in the internal combustion engine invented by Nikolas Otto in 1897 (Ahindra 2008). Alcohols have been used as fuels since the inception of the automobile. The term alcohol often has been used to denote either ethanol or methanol as a fuel. With the oil crises of 1970s, ethanol became established as an alternative fuel. Many countries started programs to study and develop fuels in an economic way from available raw materials. Countries including Brazil and the USA have long promoted domestic bioethanol production. "First generation bioethanol" is made from sugar feedstock such as cane juice (in Brazil) and molasses (in India) or from starch-rich materials such as corn (in US). Though bioethanol production from 'first generation technologies' is estimated to increase to more than 100 billion liters by 2022 (Goldemberg and Guardabasi 2009), these raw materials compete with food, are insufficient to meet the increasing demand for fuels, have negative impact on biodiversity and may even lead to deforestation to gain more farmland (Hahn-Hägerdal et al. 2006). The cumulative impact of these concerns have increased the interests in developing "second generation ethanol" from nonfood lignocellulosic materials such as agricultural residues, wood, paper and municipal solid waste, and dedicated energy crops (viz. miscanthus, switchgrass, sweet sorghum, etc.), which constitute the most abundant renewable organic component in the biosphere (Claassen et al. 1999).

Bioethanol is widely recognized as a unique transportation fuel with powerful economic, environmental and strategic attributes. As bioethanol can be produced from biomass of crop plants, it offers opportunities to improve the income levels of smallholder farmers. At a community level, farmers can cultivate energy crops that fetch an income while also meeting their food needs. Ethanol derived from biomass is the only liquid transportation fuel that does not contribute to the green house gas effect. Ethanol represents closed carbon dioxide cycle because after burning of ethanol, the released carbon dioxide is recycled back into plant material as plants use it to synthesize cellulose during photosynthesis. Ethanol production process only uses energy from renewable energy sources; no net carbon dioxide is added to the atmosphere, making ethanol an environmentally beneficial energy source. Ethanol contains $35 \%$ oxygen that helps complete combustion of fuel and thus reduces particulate emission that poses health hazard to living beings. The toxicity of the exhaust emissions from ethanol is lower than that of petroleum sources (Wyman and Hinman 1990). Thus, the use of even $10 \%$ ethanol blends reduces GHG emissions by $12-19 \%$ compared with conventional fossil fuels. Burning E 85 ( $85 \%$ ethanol) reduces the nitrogen oxide, particulate and sulfate emissions by 10,20 and $80 \%$, respectively, compared to conventional gasoline.

Bioethanol market is expected to reach $10 \times 10^{10} 1$ in 2015 (Licht 2008). The largest bioethanol producers in the world are the US, Brazil, and China. In 2009, US produced $39.5 \times 10^{9} 1$ of ethanol using corn as a feedstock while the second largest producer, Brazil, created about $30 \times 10^{9} 1$ of ethanol using sugarcane. China is nowadays investing heavily in ethanol production and is one of its largest producers (Ivanova et al. 2011). In India, the interest in biofuels is growing so as to substitute oil for achieving energy security and promote agricultural growth. Indian government has planned to achieve a target of $20 \%$ blending of fossil fuels with biodiesel and bioethanol by 2017. In addition, a national policy for biofuel has been framed including promotion of biofuel production, particularly on wastelands (Ravindranath et al. 2011).

\section{Feedstocks for bioethanol: agricultural residues}

The varied raw materials used in the manufacture of bioethanol are conveniently classified into three main types: sugars, starches, and cellulose materials. Sugars (such as cane or sweet sorghum juice, molasses) can be used directly for ethanol production via fermentation. Starches (from corn, cassava, potatoes, and root crops) must first be hydrolyzed to fermentable sugars by the action of enzymes from malt or molds. Cellulose (from wood, agricultural residues, waste sulfite liquor from pulp, and paper mills) must likewise be converted into sugars, generally by the action of acids or cellulolytic enzymes (Franks et al. 2006).

There are various forms of biomass resources in the world, which can be grouped into four categories, viz. wood product industry wastes, municipal solid waste, agriculture residues and dedicated energy crops. These biomass resources seem to be the largest and most promising future resources for biofuels production. This is because of the ability to obtain numerous harvests from a single planting, which significantly reduces average annual costs for establishing and managing energy crops, 
particularly in comparison to conventional crops (Franks et al. 2006). The global production of plant biomass, of which over $90 \%$ is lignocellulose, amounts to about $200 \times 10^{9}$ tons/year, where about 8-20 $\times 10^{9}$ tons of the primary biomass remains potentially accessible (Kuhad and Singh 1993). Lignocellulosic material represents a promising option as feedstock for ethanol production considering their output/input energy ratio, availability, low cost and higher ethanol yields. For second-generation biofuel production, utilization of renewable biomass resources has received major focus in the world. Renewable 'plant biomass' refers particularly to cheap and abundant non-food lignocellulose-rich materials available from the plants. Biomass to bioethanol process could help in mitigation of global climate change by reducing emissions (mainly $\mathrm{CO}_{2}$ ) as well as decreasing dependence upon fossil fuels. Thus, deployment of biomass resources has been projected to play an important role in sustainable development. The second-generation biofuels include hydrogen, natural gas, bio-oils, producer gas, biogas, alcohols and biodiesel. In countries like India, agricultural production of various crops like cotton, mustard, chilli, sugarcane, sorghum, sweet sorghum, pulses, oilseeds, etc. results in generation of huge amounts of wastes that do not find any alternative use and are either left in the fields or are burned. Hence, these could be used as good alternative resources to generate biofuels such as bioethanol, in an environmentally friendly manner. Use of agricultural residues helps in reduction of deforestation by decreasing our reliance on forest woody biomass. Moreover, crop residues have short harvest period that renders them more consistently available to bioethanol production (Knauf and Moniruzzaman 2004; Kim and Dale 2004; Limayema and Ricke 2012).

Maize, wheat, rice, and sugarcane are the four agricultural crops with maximum production as well as area under cultivation. These four crops are responsible for generating majority of lignocellulosic biomass in agriculture sector and rest of the agrowastes constitute only a minor proportion of the total agrowaste production in the world. Corn stover is the left over residue after harvesting corn kernel and comprises stalks, leaves, cobs, and husks. Its annual production is approximately $1 \mathrm{~kg} / \mathrm{kg}$ corn grain or 4 tons/ acre (Kim and Dale 2004; Heaton et al. 2008; Cheng and Timilsina 2011). Straw is generated during wheat grain harvest at a rate of 1-3 tons/acre annually under rigorous farming conditions. Rice straw is the leftover of rice production and includes stems, leaf blades, leaf sheaths, and the remains of the panicle after threshing. It is one of the most abundant lignocellulosic waste materials in the world. Out of the annual global production of 731 million tons of rice straw Asia alone produces 667.6 million tons. Bagasse is produced in huge amounts during sugarcane processing.
It is also a cheap renewable agricultural resource for ethanol production (Bhatia and Paliwal 2011). Most of the agricultural residues have similar contents of cellulose, hemicelluloses, and lignin, but rice straw has more silica content while wheat straw contains significant amount of pectin and proteins (Sarkar et al. 2012).

Lignocellulosic agricultural wastes have cellulose as a major component, but their chemical composition varies considerably (Table 1). Global production of major agrowastes and their bioethanol production potential are shown in Table 2. Maximum rice straw and wheat straw are generated in Asia and corn straw and sugarcane bagasse are mainly produced in America. According to an estimate, lignocellulosic biomass can be used to generate approximately 442 billion liters of bioethanol per year and if total crop residues and wasted crops are also considered, this figure can rise to 491 billion liters, about 16 times higher production than the actual global production (Kim and Dale 2004; Sarkar et al. 2012). In US alone, a total of 1,368 MT biomass are available for bioethanol production, out of which agrowastes with 428 MT constitute major proportion, followed by forestry wastes, energy crops, grains and corn, municipal and industrial wastes and other wastes contributing $370,377,87,58$ and $48 \mathrm{MT}$, respectively (Perlack et al. 2005; USDOE Biomass Program 2009; RFA 2010).

Structural organization of lignocellulosic feedstocks

Agricultural residues such as wheat straw, rice straw, bagasse, cotton stalk and wheat bran are rich in lignocellulose and primarily contain cellulose, lignin, hemicellulose, and extractives. Cellulose forms a skeleton that is surrounded by hemicellulose and lignin functioning as matrix and encrusting materials, respectively (Ingram and Doran 1995). Table 1 presents the biochemical composition of major lignocellulosic feedstocks that are being used worldwide for bioethanol production.

\section{Cell wall polysaccharides}

Classically, cell wall polysaccharides have been grouped into three fractions: cellulose, hemicellulose and pectic polysaccharides, proteins and other miscellaneous compounds (Chesson and Forsberg 1988) as discussed below.

Cellulose Cellulose, the major structural component in the plant cell wall, is a linear homo-polysaccharide consisting of anhydrous glucose units (500-15,000) that are linked by $\beta$-1,4-glycosidic bonds, with cellobiose as the smallest repetitive unit. The $\beta-1,4$ orientation of the glucosidic bonds results in the potential formation of intramolecular and intermolecular hydrogen bonds, which 
Table 1 Composition of various agricultural and other lignocellulosic residues

\begin{tabular}{|c|c|c|c|c|c|}
\hline Material & Cellulose $^{\mathrm{a}}$ & Hemicellulose & Lignin & Ash & Extractives \\
\hline Algae (green) & $20-40$ & $20-50$ & - & - & - \\
\hline Cotton, flax, etc. & $80-95$ & $5-20$ & - & - & - \\
\hline Grasses & $25-40$ & $25-50$ & $10-30$ & - & - \\
\hline Hardwoods & $45 \pm 2$ & $30 \pm 5$ & $20 \pm 4$ & $0.6 \pm 0.2$ & $5 \pm 3$ \\
\hline Hardwood barks & $22-40$ & $20-38$ & $30-55$ & $0.8 \pm 0.2$ & $6 \pm 2$ \\
\hline Softwoods & $42 \pm 2$ & $27 \pm 2$ & $28 \pm 3$ & $0.5 \pm 0.1$ & $3 \pm 2$ \\
\hline Softwood barks & $18-38$ & $15-33$ & $30-60$ & $0.8 \pm 0.2$ & - \\
\hline Cornstalk & $39-47$ & $26-31$ & $3-5$ & $12-16$ & - \\
\hline Wheat straw & $37-41$ & $27-32$ & $13-15$ & $11-14$ & - \\
\hline Newspaper & $40-55$ & $25-40$ & $18-30$ & - & - \\
\hline Chemical pulp & $60-80$ & $20-30$ & $2-10$ & - & - \\
\hline Sorghum stalks & 27 & 25 & 11 & - & - \\
\hline Corn stover & $38-40$ & 28 & $7-21$ & $3.6-7.0$ & - \\
\hline Coir & $36-43$ & $0.15-0.25$ & $41-45$ & $2.7-10.2$ & - \\
\hline Bagasse & $32-48$ & $19-24$ & $23-32$ & $1.5-5$ & - \\
\hline Rice straw & $28-36$ & $23-28$ & $12-14$ & $14-20$ & - \\
\hline Wheat straw & $33-38$ & $26-32$ & $17-19$ & $6-8$ & - \\
\hline Barley straw & $31-45$ & $27-38$ & $14-19$ & $2-7$ & - \\
\hline Sorghum straw & 32 & 24 & 13 & 12 & - \\
\hline Sweet sorghum Bagasse & $34-45$ & $18-28$ & $14-22$ & - & - \\
\hline
\end{tabular}

Ref Kuhad et al. (1997), Reddy and Yang (2005), Li et al. (2010)

${ }^{\text {a }}$ Composition represented in \%wt on dry matter basis

Table 2 Worldwide availability of major agricultural wastes and their bioethanol production potential

\begin{tabular}{lll}
\hline $\begin{array}{l}\text { Agricultural } \\
\text { wastes }\end{array}$ & $\begin{array}{l}\text { Availability } \\
\text { (million tons) }\end{array}$ & \begin{tabular}{l} 
Estimated bioethanol $_{\text {potential }^{\mathrm{a}}(\mathrm{Gl})}$ \\
\hline Wheat straw
\end{tabular} \\
Rice straw & 354.34 & 104 \\
Corn straw & 731.3 & 205 \\
Sugarcane bagasse & 128.02 & 58.6 \\
\hline
\end{tabular}

${ }^{\text {a }}$ Calculated from Sarkar et al. (2012)

make native cellulose highly crystalline, insoluble, and resistant to enzyme attack. The highly crystalline regions of cellulose in the plant cell wall are separated by less ordered amorphous regions (Chesson and Forsberg 1988).

Hemicellulose Hemicellulose is a short, highly branched polymer of pentoses (e.g. D-xylose and L-arabinose) and hexoses (e.g. D-manose, D-galactose, and D-glucose) with 50-200 units. Its acetate groups were randomly attached with ester linkages to the hydroxyl groups of the sugar rings. The role of hemicellulose is to provide a linkage between lignin and cellulose (Holtzapple 1993).

Pectic compounds and proteins Pectic polysaccharides make up approximately $35 \%$ of the primary cell walls, the main components being galactosyluronic residues. Its other major components are rhamnose, arabinose, and galactose. Pectic substances are hydrophillic and therefore have certain adhesive properties. Proteins are a minor component of the plant cell wall which may be covalently cross-linked with lignin and polysaccharides (Cassab and Varner 1988).

Phenolic compounds Three types of phenolic compounds viz. lignin, tannins and phenolic acids are found in plant cell walls. Lignin is a heterogeneous, amorphous, and crosslinked aromatic polymer where the main aromatic components are trans-coniferyl, trans-sinapyl and trans- $p$-coumaryl alcohols. Lignin is covalently bound to side groups on different hemicelluloses, forming a complex matrix that surrounds the cellulose micro-fibrils. In plant cell wall it varies from 2 to $40 \%$. The existence of strong carbon-carbon $(\mathrm{C}-\mathrm{C})$ and ether $(\mathrm{C}-\mathrm{O}-\mathrm{C})$ linkages in the lignin gives the plant cell wall strength and protection from attack by cellulolytic microorganisms (Mooney et al. 1998). Tannins are high molecular weight (500-3,000) polyphenolic compounds, composed of either hydroxyflavans, leucoanthocyanidin (flavan-3,4-diol) and catechin (flavan-3-ol) or glucose. Phenolic acids are structural components of the lignin core in plant cell wall. The presence of carboxyl and phenolic groups in phenolic acids enable such compounds to link to lignin and carbohydrates by ether or ester bonds. 


\section{Bioconversion of lignocellulosic biomass to bioethanol}

Biomass to ethanol bioconversion process consists of several steps, including pretreatment of biomass, enzymatic hydrolysis, fermentation and product recovery. Proper combination of each step is important for achieving higher bioethanol yield in a cost-effective and sustainable manner.

\section{Processing and pretreatments}

The main processing challenge in the ethanol production from lignocellulosic biomass is the feedstock pretreatment. During pretreatment, the matrix of cellulose and lignin bound by hemicellulose should be broken to reduce the crystallinity of cellulose and increase the fraction of amorphous cellulose, the most suitable form for enzymatic attack. The yield of cellulose hydrolysis after pretreatment often exceeds $90 \%$ of theoretical as compared to $20 \%$ when pretreatment is not carried out (Lynd 1996). For pretreatment of lignocellulosics, several physical, physicochemical and biological processes have been developed that improve lignocellulose digestibility in very different ways (Aden et al. 2002; Sun and Cheng 2002; Wyman et al. 2005a, b). These processes are summarized in Table 3 .

\section{Physical pretreatment methods}

Lignocellulosic biomass can be pulverized by chipping, grinding, shearing, or milling, which reduces the particle size and increases surface area, facilitating the access of cellulases to the biomass surface and increasing the conversion of cellulose. Primary size reduction employs hammer mills or Wiley mills to produce particles that can pass through 3- to 5-mm diameter sieve. Other useful physical treatment methods include pyrolysis, irradiation with gamma radiation, microwave, infrared, or sonication (Brown 2003; Mosier et al. 2005).

\section{Physico-chemical methods}

Physico-chemical methods are considerably more effective than physical methods of pretreatment. Different chemical agents employed during these processes are ozone, acids, alkali, peroxide and organic solvents. Several physicochemical methods (Table 2) are employed for pretreament of biomass before its saccharification, such as ammonia fiber explosion (AFEX) (Sun and Cheng 2002; Mosier et al. 2005), autohydrolysis (steam explosion) (Grous et al. 1986; Ramos and Fontana 1996), $\mathrm{SO}_{2}$ steam explosion (Sipos et al. 2009), acid treatment (Sun and Cheng 2002; Gamez et al. 2006) and alkali treatment (Chang and Holtzapple 2000; Kaar and Holtzapple 2000).

\section{Biological treatment}

The brown rot, white rot and soft-rot fungi such as Phanerochaete chrysosporium, Trametes versicolor, Ceriporiopsis subvermispora, and Pleurotus ostreatus are employed for biological pretreatment of lignocellulosic biomass. Besides lignin peroxidases and manganesedependent peroxidases, polyphenol oxidases, laccases and quinosine-reducing enzymes also degrade lignin by producing aromatic radicals. Biological treatment requires low energy and normal environmental conditions but the hydrolysis yield is low and requires long treatment times (Brown 2003).

Enzymatic saccharification of pretreated biomass

Cellulose hydrolysis, also known as saccharification, is the process in which the cellulose is converted into glucose. Enzymatic hydrolysis is the key to cost-effective ethanol production from lignocellulosic substrates in the long run, as it is very mild process, gives potentially high yields, and the maintenance costs are low compared to acid or alkaline hydrolysis (Kuhad et al. 1997). The process is compatible with many pretreatment methods, but materials poisonous to the enzymes need to be removed or detoxified when chemical pretreatment precedes enzymatic hydrolysis. Factors affecting enzymatic saccharification process involve substrate concentration, enzyme loading, temperature and time of saccharification (Tucker et al. 2003).

\section{Cellulase enzyme complex}

The cellulose-degrading enzymes were discovered by Reese (1976). The term cellulase complex normally refers to a set of enzymes involved in complete cellulose hydrolysis. Cellulose and the modified cellulose-degrading enzymes are divided into three major groups of enzymes: endo-glucanases (EG), exoglucanases (cellobiohydrolases, $\mathrm{CBH}$ ) and $\beta$-glucosidase (BGL) (Fig. 1) which belong to the EC 3.2.1.X class.

Endoglucanases Endo- $\beta-(1,4)$-glucanases (or 1,4- $\beta$-Dglucan-4-glucanohydrolases, EC 3.2.1.4), commonly referred to as endoglucanases, are characterized by their random hydrolysis of $\beta$ - $(1,4)$-glucosidic linkages (Wood and McCrae 1979). Acting on soluble cellulose derivatives, their random cleavage causes rapid decrease in chain length and hence changes in viscosity relative to the release of reducing end groups. When acting on cellodextrins, the 


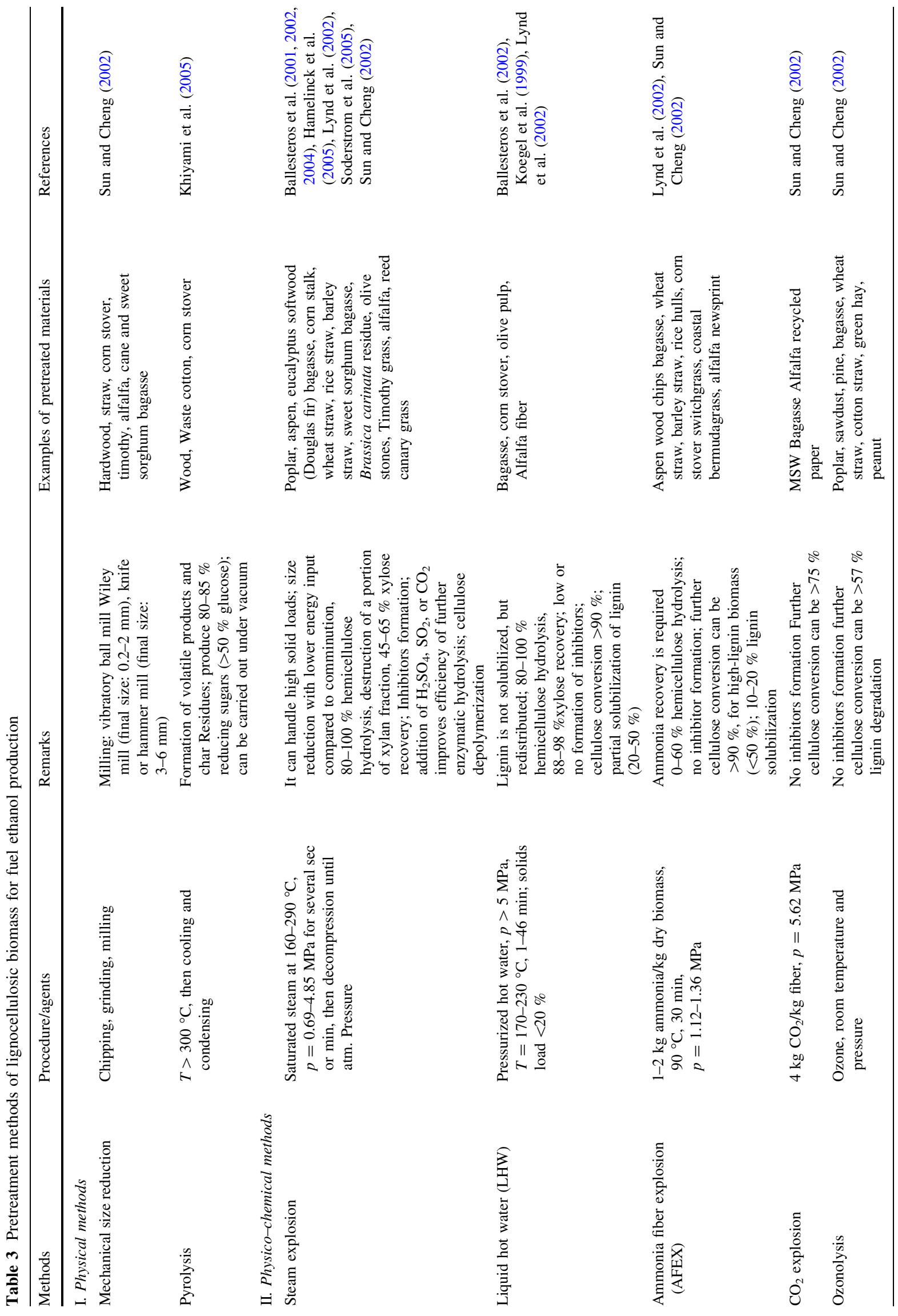




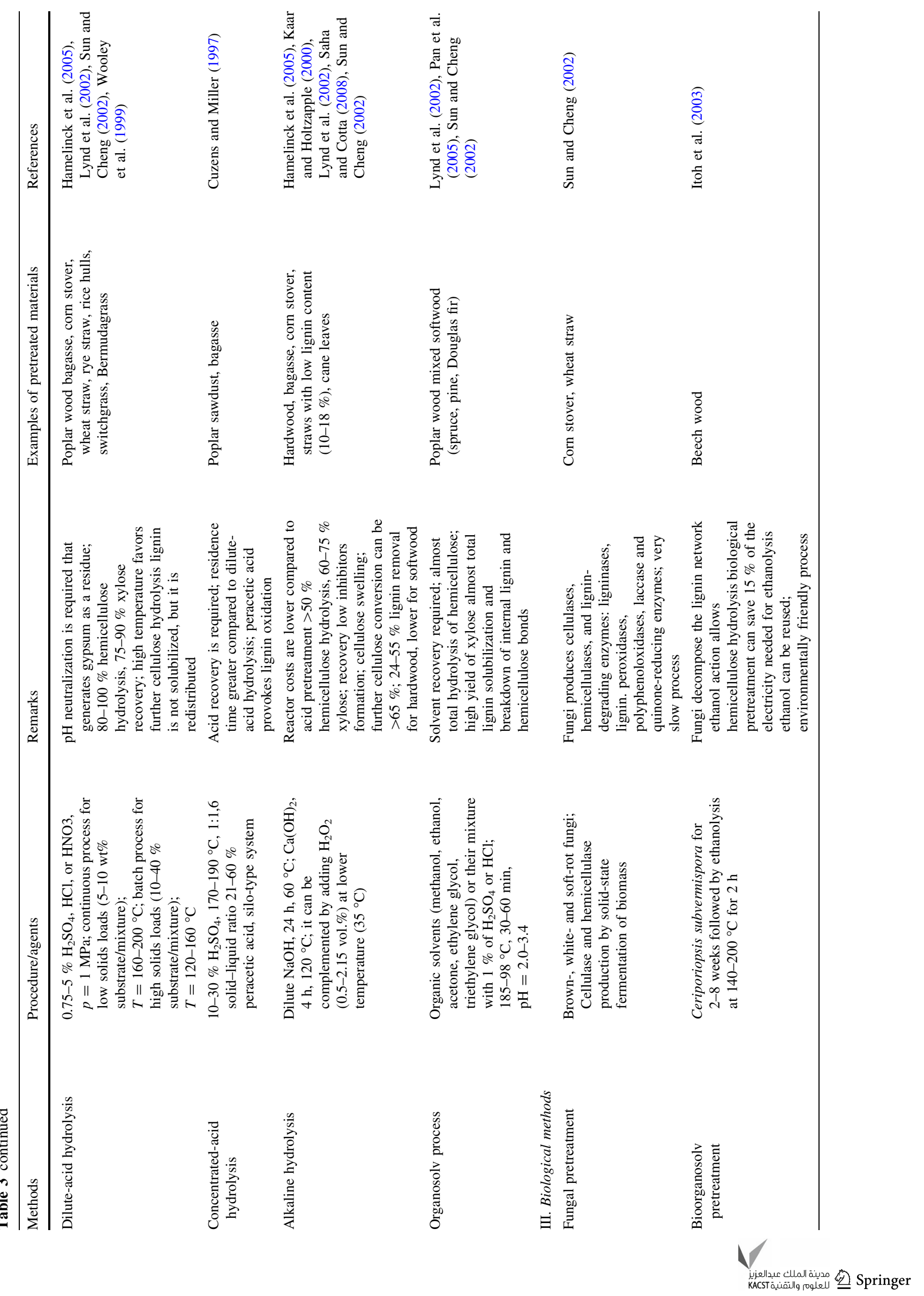




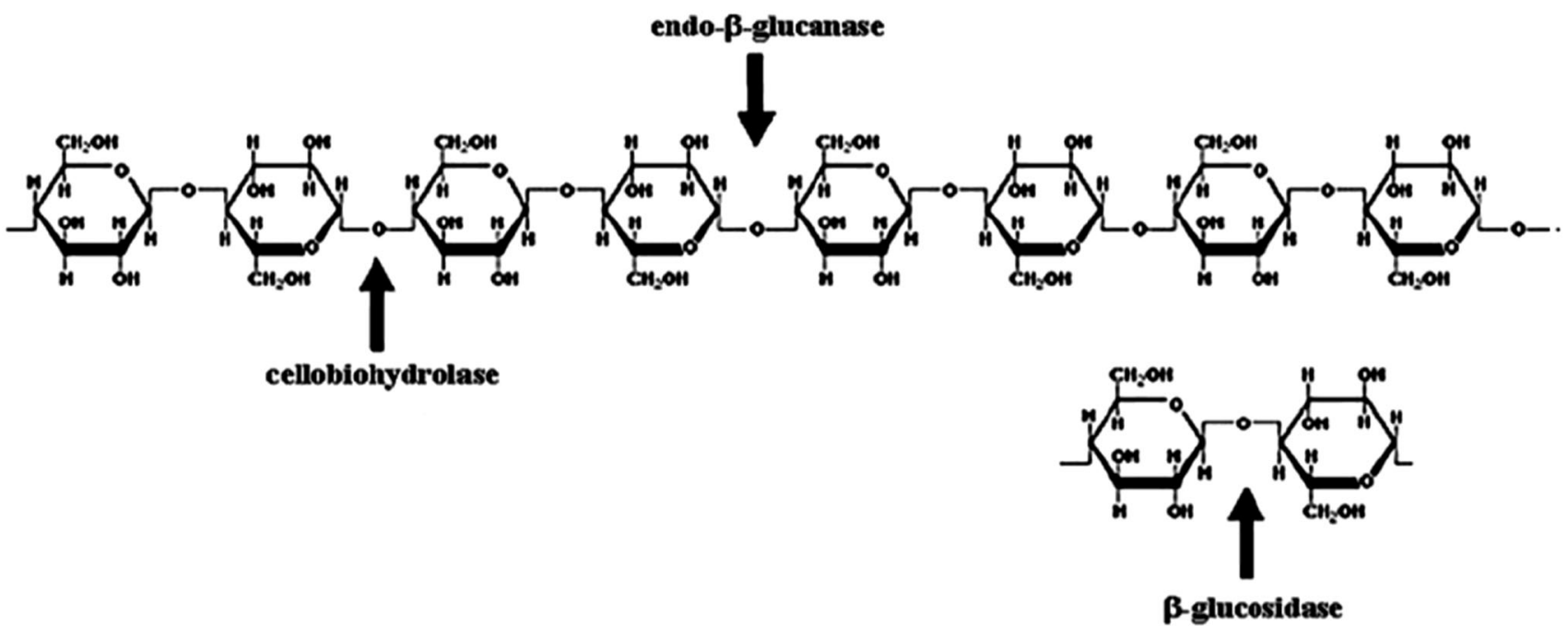

Fig. 1 Sites of action of cellulases on cellulose polymer

rate of hydrolysis increases with the degree of polymerization within the limits of substrate solubility, with cellobiose and cellotriose being the major final product.

Exoglucanases $\quad$ Exo- $\beta$-(1-4)-glucanase (or 1,4- $\beta$-D-glucan cellobiohydrolases, EC 3.2.1.91) cleave cellobiose units from the non-reducing ends of cellulose molecules. Exo- $\beta$ $(1,4)$-glucosidase (or 1,4- $\beta$-D-Glucan glucohydrolases, EC 3.2.1.74) cleaves glucose units successively from the nonreducing end of the glucan. They are distinguished from $\beta$ glucosidase by their preference for substrates of longer chain length and by the inversion of their products.

$\beta$-glucosidases $\beta$-glucosidase (or $\beta$-D-glucoside glucohydrolase, EC 3.2.1.21) hydrolyzes cellobiose and other very short chain $\beta$-1,4-oligoglucosides up to cellohexaose to form glucose. Most $\beta$-glucosidases are active on a range of $\beta$-dimers of glucose. Unlike exoglucosidases, the rate of hydrolysis of cellobiose decreases markedly as the degree of polymerization of the substrate increases.

\section{Hemicellulolytic enzymes}

In xylan degradation, endo-1,4- $\beta$-xylanase, $\beta$-xylosidase, $\alpha$-glucuronidase, $\alpha$-L-arabinofuranosidase and acetylxylan esterase act on different heteropolymers, while during glucomannan degradation, $\beta$-mannanase and $\beta$-mannosidase cleave the polymer backbone (Niehaus et al. 1999).

\section{Synergism between cellulases}

When the combination of two enzymes is more efficient than the sum of the enzymes acting alone, the two enzymes have synergy. The complete hydrolysis of cellulose to glucose requires a combination of enzymes (endo-, exoglucanse and $\beta$-glucosidase) which work in a synergistic manner for hydrolysis of both native and modified cellulose (Irwin et al. 1993). Presumably the EG makes internal cuts in the cellulose chain, and thereby provides new accessible chain ends for the cellobiohydrolase/exoglucanase and $\beta$-glucosidase to work on to gain increased hydrolytic activity (Fig. 2) and due to synergistic effect, each enzyme speeds up the action of the other, with a resulting increase of hydrolysis yield. This model for the synergy between endoglucanases and exoglucanases is called the endo-exo model (Beguin and Aubert 1994).

\section{Microbial cellulases}

In nature there are many microorganisms that produce cellulolytic enzymes (cellulases). The cellulolytic organisms can be sorted into two different subcategories depending on their enzyme organization in the cell: (a) the microorganism with their cellulases organized into multienzyme complexes called cellulosomes, e.g. Clostridium thermocellum and Cellulomonas. (b) The cellulolytic organisms producing non-complexed cellulase that are not attached to one another, and act individually and cooperatively on cellulose, and by doing this gain strong synergy effects. Examples of fungi from this class are T. reesei and Humicola grisea and of bacteria, Streptomyces lividans and Cellulomonas fimi (Bayer et al. 1998). Trichoderma spp. (e.g. T. reesei, T. viride, T. longibrachiatum, T. pseudokoningii and $T$. harzianum) are ideal cellulolytic model organisms for studying cellulose degradation since these secrete large amounts of cellulases. To date, two CBHs (Cel6A and Cel7A), and at least five EGs (Cel5A, Cel7B, Cel12A, Cel45A, and Cel61A), have been found in the 


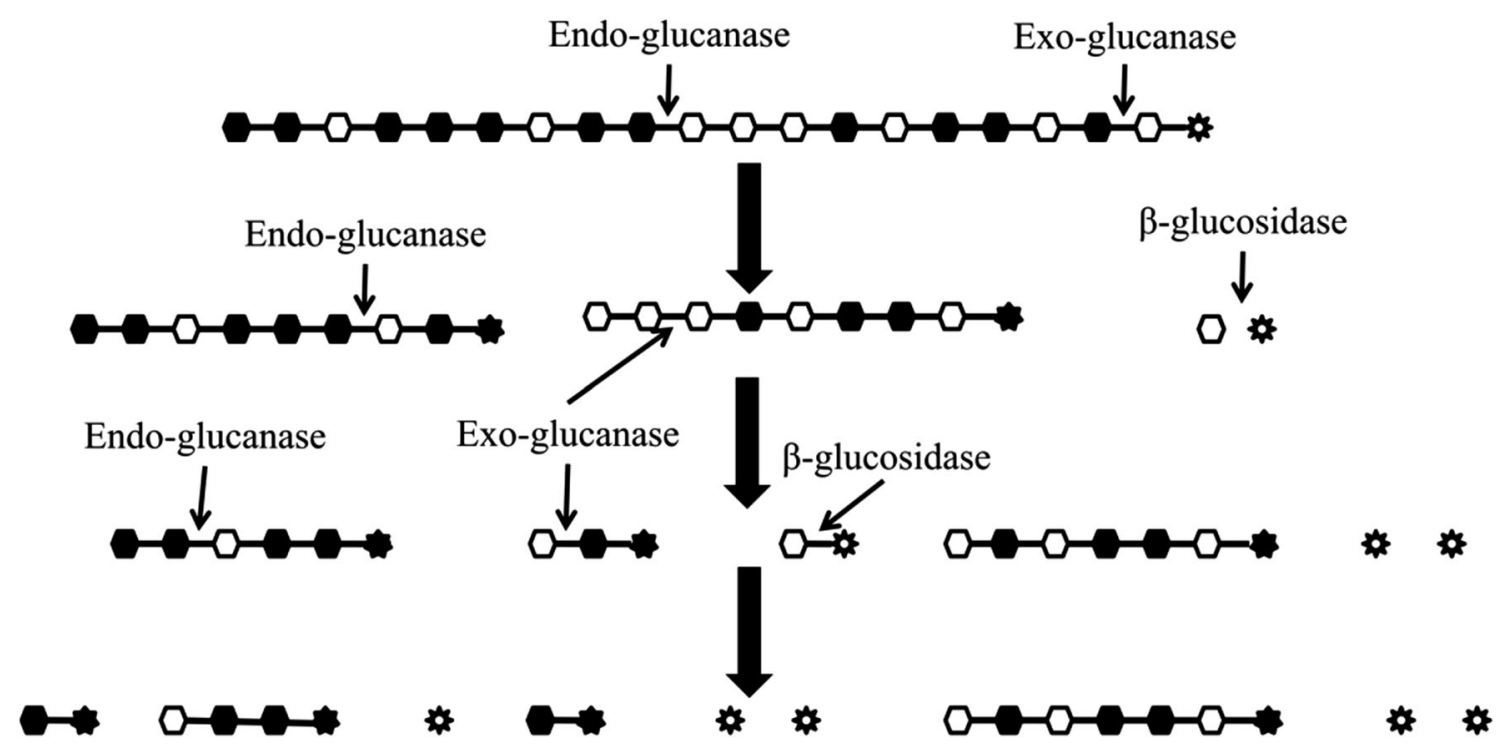

Fig. 2 The endo-exo model for synergy between endoglucanase, exoglucanase and $\beta$-glucosidase in a cellulolytic system during cellulose hydrolysis. $\mathbf{\$}=$ reducing end; $\mathbf{w}=$ modified reducing end; $-=\beta(1,4)$ linkage; $\mathbf{O}=$ modified glucose; $\mathbf{O}=$ unmodified glucose

Table 4 Properties of $T$. reesei Cellulases

\begin{tabular}{|c|c|c|c|c|c|c|c|}
\hline Enzyme & New name & $\begin{array}{l}\text { Molecular } \\
\text { mass }(\mathrm{kDa})\end{array}$ & $\mathrm{pI}$ & Conc $(\%)^{\mathrm{b}}$ & Stereo-selectivity & $\begin{array}{l}\text { No. of } \\
\text { residues }\end{array}$ & $\begin{array}{l}\text { Position } \\
\text { of CBM }\end{array}$ \\
\hline $\mathrm{CBH} \mathrm{I}$ & Cel 7A & $59-68$ & $3.5-4.2$ & $50-60$ & Retaining & 497 & $\mathrm{C}$ \\
\hline CBH II & Cel 6A & $50-58$ & $5.1-6.3$ & $15-18$ & Inverting & 447 & $\mathrm{~N}$ \\
\hline EG1 & Cel 7B & $50-55$ & 4.6 & $12-15$ & Retaining & 436 & $\mathrm{C}$ \\
\hline EG II & Cel 5A & 48 & 5.5 & $9-11$ & Retaining & 397 & $\mathrm{~N}$ \\
\hline EG III & Cel 12A & 25 & 7.4 & $0-3$ & Retaining & 218 & $\mathrm{Na}^{\mathrm{b}}$ \\
\hline EG IV & $\mathrm{Cel} 45 \mathrm{~A}$ & $37^{\mathrm{a}}$ & $\mathrm{Na}$ & na & $\mathrm{Na}$ & 344 & $\mathrm{C}$ \\
\hline EG V & Cel 61A & $23^{\mathrm{a}}$ & $2.8-3.0$ & $0-3$ & Inverting & 270 & $\mathrm{C}$ \\
\hline BGL I & Cel 3A & 71 & 8.7 & $\mathrm{Na}$ & $\mathrm{Na}$ & $\mathrm{Na}$ & $\mathrm{Na}$ \\
\hline BGL II & Cel 1A & 114 & 4.8 & $\mathrm{Na}$ & $\mathrm{Na}$ & $\mathrm{Na}$ & $\mathrm{Na}$ \\
\hline
\end{tabular}

Ref Tolan (2002)

$C B H$ cellobiohydrolase, $E G$ endoglucanase, $B G L$ beta-glucosidase

${ }^{\text {a }}$ calculated according to the amino acid sequence deducted from gene sequence

${ }^{\mathrm{b}} \mathrm{Cel} 12 \mathrm{~A}$ does not have a Cellulose binding module

cellulolytic system of $T$. reesei. These enzymes belong to six different GH families, 5, 6, 7, 12, 45, and 61 (Table 4). Today several species of cellulase producing Penicillium spp. are known (e.g. P. citrinum P. occiantalis, $P$. italicum, etc.). Moreover, many species of Aspergillus such as $A$. nidulans, $A$. niger and $A$. oryzae are also known as potential cellulase producers (Pocas-Fonseca and Maranhac 2005).

\section{Optimization of culture conditions for cellulase production}

Cellulase production using fungal cultures is a complex system. Many factors affect cellulase production including nutrient availability, $\mathrm{pH}$, temperature, dissolved oxygen concentration, agitation speed, etc.

Medium composition No general medium composition can be given for growth and optimum cellulase production by all microbes, since the medium must be adapted to the organism in use. Basal medium after Mandels and Weber (1969) has been most frequently used for cellulase production by $T$. viridae, either directly or with slight modifications. Among the cellulosic materials, sulfite pulp, printed papers, mixed waste paper, wheat straw, paddy straw, sugarcane bagasse, jute stick, carboxymethylcellulose corncobs, groundnut shells, cotton, ball milled barley 
straw, delignified ball milled oat spelt xylan, larch wood xylan, etc. have been used as the substrates for cellulase production. Carboxymethycellulose or cereal straw (1\%, $\mathrm{w} / \mathrm{w})$ has been reported as the best carbon source for CMCase and $\beta$-glucosidase production using Chaetomium globosum as the cellulolytic agent. Further, $3 \%$ malt extract or water hyacinth has also been optimum for CMCase, FPase and $\beta$-glucosidase as observed with lactose as the additional carbon sources. However, the saccharification of alkali-treated bagasse at higher substrate levels (up to $4 \% \mathrm{w} / \mathrm{v}$ ) has also been reported. Addition of Ammonium sulfate $(0.5 \mathrm{~g} / \mathrm{l})$ leads to maximum production of cellulases. However, an increase in the level of $\beta$-glucosidase but decrease in endoglucanase and exoglucanase levels was reported when corn steep liquor $(0.8 \% \mathrm{v} / \mathrm{v})$ was added to synthetic cellulose, wheat straw and wheat bran as the substrates. Phosphorus is an essential requirement for fungal growth, metabolism and several intracellular processes. Different phosphate sources such as potassium dihydrogen phosphate, tetra-sodium pyrophosphate, sodium $\beta$-glycerophosphate and dipotassium hydrogen phosphate have been evaluated for their effect on cellulase production (Garg and Neelakantan 1982).

Temperature Temperature has a profound effect on lignocellulosic bioconversion. The temperature range for cellulase production is generally within $25-35{ }^{\circ} \mathrm{C}$ for a variety of microbial strains, e.g. T. reesei, Thielavia terrestris, Mycelieopthora fergussi, Aspergillus wentii, Penicillum rubrum, Aspergillus niger, Aspergillus ornatus and Neurospora crassa. Some of the thermophilic fungi, having maximum growth at or above $45-50{ }^{\circ} \mathrm{C}$, had produced cellulase with maximum activity at $50-78{ }^{\circ} \mathrm{C}$ ( $\mathrm{Li}$ et al. 2011).

pH of medium $\mathrm{pH}$ has been known to affect enzyme and cells metabolism tremendously. When the environmental $\mathrm{pH}$ is over the operational $\mathrm{pH}(\mathrm{pH} 2.0-\mathrm{pH} 7.0)$, the intracellular $\mathrm{pH}$ and enzyme activity are greatly influenced. For cellulase production by $T$. reesei using sugarcane bagasse, an optimum $\mathrm{pH}$ range of 5.0-6.0 has been suggested. $\mathrm{pH}$ cycling method has been used successfully in the past to obtain high cellulase productivity from 25.0 to $38.75 \mathrm{IU} / \mathrm{l} / \mathrm{h}$ using $3 \%$ cellulose and $T$. reesei $\mathrm{QM} 9414$. In addition, the fungal cellulases have been found to have the highest catalytic capability between $\mathrm{pH} 3.5$ and 6.0 at $50{ }^{\circ} \mathrm{C}$ (Bracey 1998; Kansoh 1998).

Oxygen concentration Oxygen is required for cell growth of most eukaryotes; therefore, cell growth is affected by agitation tremendously. For cellulase production, the percentage of dissolved oxygen is typically maintained above $30 \%$. Cells die when oxygen is not enough and they stop growing afterwards.

\section{Cellulolytic fungal consortium}

Although significant advances have been made, a considerable amount of work is still required to enhance the production efficiency of cellulase enzymes. One possible way of improving this situation is to have a mixture containing enzymes of different origins (fungal and/or bacterial). Improved enzyme production by coculturing of two or more microbial strain is being used increasingly for enhanced enzyme production (Garcia-Kirchner et al. 2005). Enhanced cellulose hydrolytic activities have also been observed by the co-cultivation of A. ellipticus and A. fumigatus (Gupte and Madamwar 1997), co-culture of $A$. flavus and A. niger (Saini et al. 2013), co-culture of $A$. niger and $T$. reesei and co-culture of $T$. reesei and $A$. phoenicis (Gutierrez-Correa and Tengerdy 1997).

\section{Purification and characterization of fungal cellulases}

Culture filtrates from fungal growth often contain a mixture of several extracellular enzymes besides cellulases and hemicellulases and present considerable purification problems. Therefore, multiple purification steps, including different chromatographic runs, are needed to purify cellulase components (Stahlberg et al. 1988). Various chromatographic techniques have been described in the literature for purification of cellulase enzyme such as molecular exclusion, affinity chromatography, ion-exchange chromatography, chromatofocusing, fast protein liquid chromatography (FPLC) and hydrophobic interaction chromatography (HIC) (Tomaz and Queiroz 1999). The biochemical characteristics of $\beta$-glucosidase and cellulase are summarized in Table 5.

\section{Commercial cellulases}

The cost of cellulase enzymes is widely considered an important factor in the commercialization of lignocellulosic biomass-to-ethanol processes (Wright 1988). A large number of industries are manufacturing cellulase enzymes globally (Table 6). The enzyme producers Genencor International and Novozymes A/S have achieved increased enzyme activity and reduced 30-fold cost of production. Genencor developed a blend of genetically enhanced enzymes that act in synergy to convert cellulose to sugars (http://www.nrel.gov/awards/ 2004hrvtd.html). Cellic CTec3 is a state-of-the-art cellulase and hemicellulase complex that allows for the most costefficient conversion of pretreated lignocellulosic materials to fermentable sugars compared to any other cellulase or enzyme complex available in the market for cellulosic ethanol production (http://www.bioenergy.novozymes.com/en/ cellulosic-ethanol/CellicCTec3/Pages/default.aspx). 
Table 5 Biochemical properties of fungal $\beta$-glucosidase and cellulases

\begin{tabular}{|c|c|c|c|c|}
\hline Source & $\begin{array}{l}\mathrm{Mr} \\
(\mathrm{kDa})\end{array}$ & $\begin{array}{l}\text { Quaternary } \\
\text { structure }\end{array}$ & $\begin{array}{l}\text { Opt. } \\
\mathrm{pH}\end{array}$ & $\begin{array}{l}\text { Opt. } \\
\text { Temp } \\
\left({ }^{\circ} \mathrm{C}\right)\end{array}$ \\
\hline \multicolumn{5}{|l|}{$\beta$-glucosidases } \\
\hline Aspergillus niger & 105 & Dimer & 5 & 55 \\
\hline Aspergillus niger & 330 & Tetramer & $4.6-5.3$ & 70 \\
\hline Candida peltate & 43 & Monomer & 5 & 50 \\
\hline Ceriporiopsis subvermispora & 110 & NR & 3.5 & 60 \\
\hline Fomitipsis pinicola & 105 & Monomer & 4.5 & 50 \\
\hline Melanocarpus sp. & 92 & Monomer & 6 & 60 \\
\hline $\begin{array}{l}\text { Phanerochaete } \\
\text { chrysosporium }\end{array}$ & 114 & NR & $4-5.2$ & NR \\
\hline Penicillium purpurogenum & 110 & Monomer & 5 & 65 \\
\hline \multicolumn{5}{|l|}{ Cellulases } \\
\hline T. reesei & 48 & Monomeric & $4.0-5.0$ & 50 \\
\hline A. niger & 31 & Monomeric & 4.0 & 30 \\
\hline A. nidulans & 83 & NR & 5.0 & 50 \\
\hline T. harzianum & 78 & Monomeric & $7.7-8.0$ & 40 \\
\hline Geotrichum sp. & 80 & Monomeric & 5.5 & 55 \\
\hline Trichoderma sp. & 51 & Monomeric & 5 & 50 \\
\hline F. oxysporum & 42.7 & Monomeric & 5.0 & 75 \\
\hline
\end{tabular}

Ref Rashid and Siddiqui (1998)

$N R$ not reported

\section{Visualizing structural changes in hydrolyzed bagasse}

To detect morphological and structural changes in polymers, some physico-chemical (thermal analysis, X-ray diffraction, gel permeation chromatography), spectroscopic
(Infrared and Raman spectroscopy, nuclear magnetic resonance and mass spectroscopy) and microscopic [scanning electron microscopy (SEM), atomic force microscopy (AFM), transmission electron microscopy (TEM), and chemical force microscopy (CFM)] (Samir et al. 2005) methods are consistently being used in the literature (Volke-Spulveda 1998). Standard methods generally employed to examine biodegradation of biopolymers are: visual observations, weight loss measurements through determination of residual polymer, changes in mechanical properties and molar mass and radio-labeling. A number of other techniques have also been used to assess the biodegradability of polymeric material. These include differential scanning colorimetry (DSC), nuclear magnetic resonance spectroscopy (NMR), X-ray photoelectron spectroscopy (XPS), X-ray Diffraction (XRD), contact angle measurements and water uptake Carmen et al. (2009). More recently, Fourier transform infrared spectroscopy (FTIR) and simultaneous TG-DTG-DTA have been used to study biodegradation of polymers (Hadad et al. 2005).

Fermentation and product recovery

The biomass is hydrolyzed by cellulolytic enzymes into fermentable sugars (pentoses or hexoses), which are fermented to ethanol by several microorganisms. For making ethanol production commercially viable, an ideal microorganism should utilize broad range of substrates, with high ethanol yield, titre and productivity, and should have high tolerance to ethanol, temperature and inhibitors present in hydrolysate. Some of the major characters of a viable ethanol process are listed in Table 7.
Table 6 Commercially available cellulases

Ref Nieves et al. (1998)

\begin{tabular}{|c|c|c|c|c|c|}
\hline Product name & Company & Source & $\mathrm{pH}$ & Temp $\left({ }^{\circ} \mathrm{C}\right)$ & Form \\
\hline Biocellulase TRI & Quest Intl. (USA) & T. reesei & $4.0-5.0$ & 50 & Liquid \\
\hline Biocellulase A & Quest Intl. (USA) & A. niger & 5.0 & 55 & Powder \\
\hline Celluclast $1.5 \mathrm{~L}$ & Novo Nordisk, (Danbury, CT) & T. reesei & 5.0 & 50 & Liquid \\
\hline Cellulase TAP $10^{6}$ & Amano Enzyme (Troy, VA) & T. viride & 5.0 & 50 & Powder \\
\hline Cellulase AP30 K & Amano Enzyme (Troy, VA) & A. niger & 4.5 & 60 & Powder \\
\hline Cellulase TRL & Solvay Enzymes (Elkhart, IN) & T. reesei & 4.5 & 50 & Liquid \\
\hline Econase $\mathrm{CE}$ & Alko-EDC (USA) & T. reesei & 5.0 & 50 & Liquid \\
\hline Multifect CL & Genencor Intl. (USA) & T. reesei & 4.5 & 50 & Liquid \\
\hline Multifect GC & Genencor Intl. (USA) & T. reesei & 4.0 & 50 & Liquid \\
\hline Spezyme & Genencor Intl. (USA) & T. reesei & 4.0 & 50 & Liquid \\
\hline $\begin{array}{l}\text { Ultra-Low Microbial } \\
\text { (ULM) }\end{array}$ & Iogen, (Ottawa, Canada) & T. reesei & NA & NA & Liquid \\
\hline Cellic CTec 2 & Novozymes (Bagsvaerd, Denmark) & $\begin{array}{l}\text { Enzyme } \\
\text { cocktail }\end{array}$ & NA & NA & Liquid \\
\hline Cellic CTec 3 & Novozymes (Bagsvaerd, Denmark) & $\begin{array}{l}\text { Enzyme } \\
\text { cocktail }\end{array}$ & NA & NA & Liquid \\
\hline
\end{tabular}


Table 7 Important traits for bioethanol fermentation process

\begin{tabular}{ll}
\hline Trait & Requirement \\
\hline Bioethanol yield & $\begin{array}{c}>90 \% \text { of theoritical } \\
\text { maximum }\end{array}$ \\
Bioethanol tolerance & $>40 \mathrm{~g} / \mathrm{l}$ \\
$Y_{\mathrm{P} / \mathrm{S}}$ & $\mathrm{Close}$ to $0.5 \mathrm{~g} / \mathrm{g}$ \\
$Q_{\mathrm{P}}$ & $>1 \mathrm{~g} / \mathrm{l} / \mathrm{h}$ \\
$\begin{array}{l}\text { Robust growth and simple growth } \\
\text { requirement }\end{array}$ & $\begin{array}{l}\text { Inexpensive medium } \\
\text { Culture growth conditions retard }\end{array}$ \\
contaminants & Acidic pH or higher \\
\hline
\end{tabular}

Ref Dien et al. (2003), Balat et al. (2008)

Integrated bioprocesses for saccharification and fermentation

As shown in Fig. 3, various saccharification and fermentation bioprocess integrations have been reported. First is separate (or sequential) hydrolysis and fermentation (SHF), a two-stage process involving saccharification of the substrate, followed by the fermentation of saccharified fluid, separately. Main features of SHF include optimal operating conditions for each step and minimal interactions between hydrolysis and fermentation steps. However, SHF process is limited by end-product inhibition and chances of contaminations, which may decreases ethanol yield (Balat et al. 2008; Sanchez and Cardona 2008; Neves et al. 2007; Sarkar et al. 2012). Second process configuration is simultaneous saccharification and fermentation (SSF), in which hydrolyzes of cellulose is consolidated with the direct fermentation of the produced glucose, avoiding the problem of product inhibition associated with enzymes. Main advantages of simultaneous saccharification and fermentation process are comparatively lower costs, higher ethanol yields due to removal of feedback inhibition on enzymatic saccharification and reduction in the required number of vessels or reactors. Some of the disadvantages of SSF are different optimum conditions for enzyme hydrolysis and fermentation processes (Bjerre et al. 1996; Hamelinck et al. 2005; Neves et al. 2007; Balat et al. 2008; Sarkar et al. 2012). The most common and robust fermenting microorganisms employed in ethanol production are $S$. cerevisiae and Z. mobilis. Ethanol production from sugars derived from starch and sucrose has been commercially dominated by this yeast. However, S. cereviseae is capable of converting only hexose sugars to ethanol. The most promising yeasts that have the ability to use both pentoses and hexoses are Pichia stipitis, Candida shehatae and Pachysolan tannophilus. Thermotolerant yeasts, such as Kluyveromyces marixianus, could be more suitable for ethanol production at industrial level, because of their ability to ferment at higher temperatures. In high-temperature process energy savings can be achieved through a reduction in cooling costs. Hence, thermotolerant yeasts are highly desirable in SSF process. Another strategy for ethanol fermentation is simultaneous saccharification and co-fermentation (SSCF), in which co-fermentation of hexoses and pentoses is carried out. In SSCF the co-fermenting microorganisms need to be compatible in terms of operating $\mathrm{pH}$ and temperature (Neves et al. 2007). However, the ability to ferment pentoses along with hexoses is not widespread among microorganisms and lack of ideal co-fermenting microorganism is one of the greatest obstacles in industrial production of second-generation ethanol (Talebnia et al. 2010). Sometimes co-culture technique proves to be a useful technology whereby a combination of hexose and pentose fermenting microorganisms is utilized for complete utilization of biomass sugars. For example, co-culture of Candida shehatae and Saccharomyces cerevisiae was reported as suitable for the SSCF process (Neves et al. 2007). One more configuration for ethanol

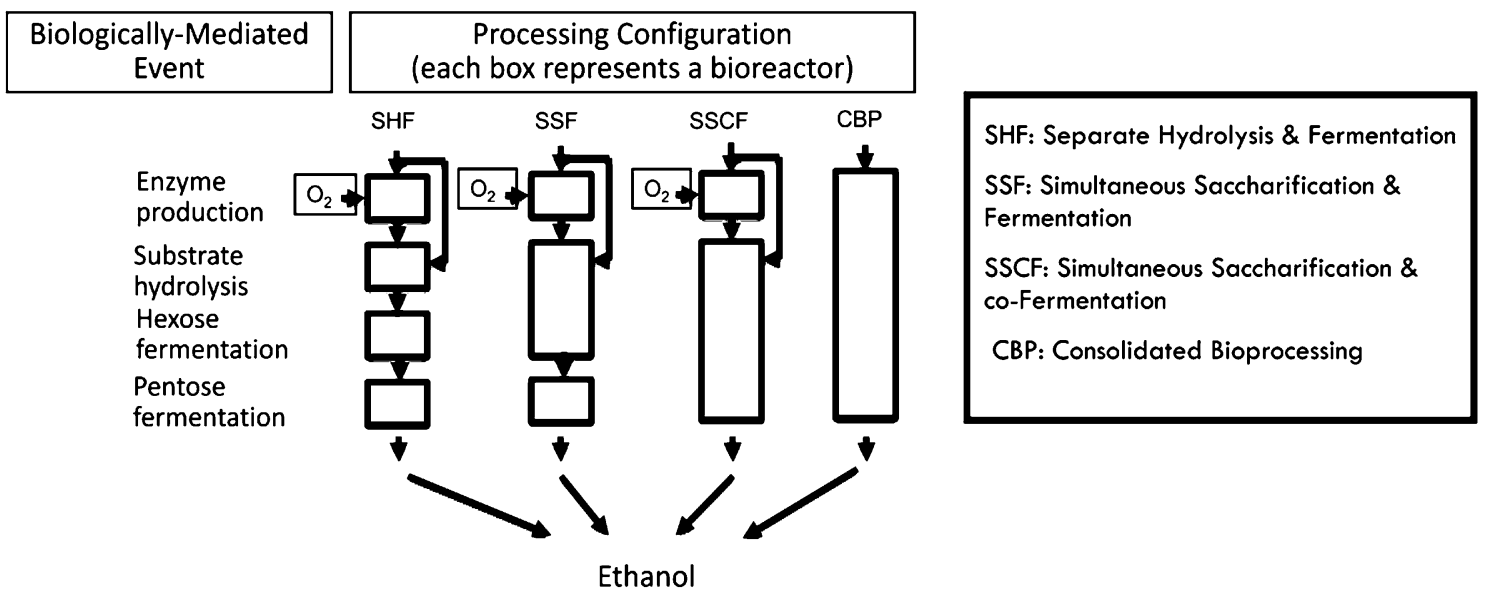

Fig. 3 Process configurations for conversion of lignocellulosic biomass to bioethanol 
Table 8 Bioethanol production from major agroresidues

\begin{tabular}{|c|c|c|}
\hline Biomass & Fermenting microorganism & Ethanol yield or titre \\
\hline \multirow[t]{2}{*}{ Wheat straw } & $\begin{array}{l}\text { Pichia stipitis NRRL Y-7124 (strain adapted to acid } \\
\text { hydrolysate inhibitors) }\end{array}$ & $0.35 \mathrm{~g} / \mathrm{g}$ yield \\
\hline & Pichia stipitis A & $0.41 \mathrm{~g} / \mathrm{g}$ yield \\
\hline Rice straw & $\begin{array}{l}\text { Candida shehatae NCL-3501 (co-ferment glucose and } \\
\text { xylose) } \\
\text { S. cerevisiae ATCC } 26603 \text { (only ferment glucose) }\end{array}$ & $\begin{array}{l}0.45 \mathrm{~g} / \mathrm{g} \text { and } 0.37 \mathrm{~g} / \mathrm{g} \text { from autohydrolysate and acid } \\
\text { hydrolysate, respectively }\end{array}$ \\
\hline \multirow[t]{2}{*}{ SCB } & $\begin{array}{l}\text { Pichia stipitis BCC15191 (glucose-xylose co- } \\
\text { fermenting strain) }\end{array}$ & $0.29 \mathrm{~g} / \mathrm{g}$ yield \\
\hline & $\begin{array}{l}\text { Genetically modified E. coli KO11 (glucose and xylose } \\
\text { co-fermenting strain) }\end{array}$ & $91.50 \%$ yield and $3.15 \%(\mathrm{w} / \mathrm{v})$ ethanol titre \\
\hline
\end{tabular}

Ref Sarkar et al. (2012)

fermentation is consolidated bioprocessing (CBP). In this process, ethanol and all required enzymes are produced by a single microorganism or microbial community, in the same reactor. The process is also known as direct microbial conversion (DMC). The main advantage of CBP is that its application avoids the cost involved in purchase or production of enzymes (Hamelinck et al. 2005; Lynd et al. 2005). Approached pathways in the development of CBP organisms are described by Lynd et al. (2002). Bacteria such as Clostridium thermocellum and some fungi including Neurospora crassa, Fusarium oxysporum and Paecilomyces sp. have shown this type of activity. However, CBP is a less-efficient process with poor ethanol yields and longer fermentation time of more than 3-4 days. Significant cost reductions are expected when progressing from improved SSF via SSCF to CBP. Table 8 summarizes the bioethanol production from some major agroresidues.

Optimization of saccharification and fermentation bioprocess

Experimental design and statistical analysis for optimization of process conditions are some of the most critical stages in the development of an efficient and economic bioprocess. Classical (such as one factor at a time) and statistical methodologies are available for optimizing process conditions (such as response surface methodology, RSM). RSM is an efficient statistical technique for optimization of multiple variables to predict the best performance conditions with a minimum number of experiments. These designs are used to find improved or optimal process settings, troubleshoot process problems and weak points and make a product or process more robust against external and noncontrollable influences. Full factorial, partial factorial, Box-Behnken and central composite rotatable designs (CCRD) are the most common techniques used for process analysis and monitoring (Sasikumar and Viruthagiri 2008). This method has been in use for hydrolysis of a wide variety of materials to find the optimum conditions for different lignocellulosic biomasses (Talebnia et al. 2010; Saini et al. 2013) and for standardizing SSF for production of ethanol from pretreated sugarcane bagasse by cellulase and yeast Kluyveromyces fragilis (Sasikumar and Viruthagiri 2008).

\section{Economic considerations for cellulosic ethanol production}

To be competitive, and economically acceptable, the cost for bioconversion of biomass to liquid fuel must be lower than the current gasoline prices (Subramanian et al. 2005). It seems, however, much more attainable because of increasing efforts of researchers working towards improvisation in the efficiency of biomass conversion technologies. However, there is still huge scope to bring down the cost of biomass-toethanol conversion. The cost of feedstock and cellulolytic enzymes are the two important parameters for low-cost ethanol production. Biomass feedstock cost represents around $40 \%$ of the ethanol production cost. An analysis of the potential of bioethanol in short and long term (2030) in terms of performance, key technologies and economic aspects such as cost per kilometer driven has been conducted recently by Hamelinck et al. (2005).

The choice of feedstock for ethanol production depends upon its availability and the ongoing uses. Some dedicated energy sources like damaged rice, sorghum grains and sweet sorghum bagasse, sunflower stalks and hulls, Eicchornia crassipies, P. brava, alfalfa fibers, residual starch and crushed wheat grains, agro waste, and Saccharum spontaneum are more feasible sources for bioethanol production. The use of integrated approach (Process engineering, fermentation and enzyme and metabolic engineering) could improve the ethanol production economics. Aristidou and Penttila (2000) reported that the total cost of cellulosic ethanol will be dropped from more than 
$\$ 1.0$ to $\sim \$ 0.3-0.5 / 1$, with a projected cost of less than $\$ 0.25 / 1$ in the near future. Wooley et al. (1999) have explained the further economic analysis of bioethanol (\$0.78/gallon) and suggested a projected cost of as low as $\$ 0.20 / 1$ by 2015 if enzymatic processing and biomass improvement targets are met. The projected cost of ethanol production from cellulosic biomass as per the earlier estimates (\$4.63/gallon in 1980) has been reduced by almost a factor of four ( $\$ 1.22 /$ gallon) over the last 20 years.

The distillation cost of per unit amount of ethanol produced is substantially higher at low ethanol concentrations; the researchers have dealt with the idea of concentrating sugar solutions prior to fermentation. Ethanol distillation cost can be further improved using membrane distillation process. It has the lowest operational cost, simple to use and is easy to maintain and is the most efficient and costeffective option among the available distillation processes (Camacho et al. 2013).

\section{Challenges and future outlook}

Lignocellulosic biomass has long been advocated as a key feedstock for cost-effective bioethanol production in an environment-friendly and sustainable manner. Lignocellulose-rich agricultural wastes/residues are abundant and renewable resources for second-generation bioethanol production. Till now research on utilization of agricultural residues for second-generation bioethanol production has shown very promising results worldwide. Several lab and pilot scale as well as demonstration studies for cellulosic ethanol production from agrowastes have been reported successful but still there exists a huge gap between the projected and actual bioethanol production at industrial level. Therefore, to make full use of these cheap, abundant and renewable resources for economically feasible bioethanol production, several difficulties have yet to be overcome. These challenges include (1) collection, harvesting, supply and handling of agrowastes; (2) costeffective pretreatment technology; (3) reduction in cost of cellulolytic enzymes; (4) achieving efficient depolymerization of cellulose and hemicellulose into fermentable monomeric sugars by development of more efficient enzyme blends/cocktails; (5) use of higher biomass loadings for achieving higher yields of fermentable sugars and thus high titers of ethanol; (6) use of efficient thermotolerant yeast strains capable of fermentation at temperatures more close to optimum for cellulolytic enzymes; and finally, (7) xylose and glucose co-fermentation, and the use of recombinant/metabolically engineered microbial strains. Considering the huge availability of feedstocks from agriculture and other sources and tremendous efforts being carried out to make second-generation biofuel production more cost-effective, there seems huge scope for the largescale production of second-generation biofuels in near future. This will certainly involve elimination of the current technology hurdles of lignocellulose to bioethanol conversion process by making microbial processes more efficient.

\section{Conclusions}

Lignocellulosic biomass-derived second-generation biofuels are promising alternatives to petroleum-based fossil fuels. The utilization of agricultural residues and wastes for bioethanol production is a cost-effective and environmental-friendly approach for sustainable development. Considering the recent research progress in the fields of enzyme production, pretreatment, as well as metabolic engineering of yeasts, production of bioethanol from lignocellulosic agricultural wastes will certainly prove to be a feasible technology to achieve energy security in very near future.

Acknowledgments Authors JKS and LT thank Director, Experiment Station, GBPUA\&T, Pantnagar, India, for providing necessary research facilities.

Conflict of interest All the authors declare that they have no conflict of interest in the publication.

Open Access This article is distributed under the terms of the Creative Commons Attribution License which permits any use, distribution, and reproduction in any medium, provided the original author(s) and the source are credited.

\section{References}

Aden A, Ruth M, Ibsen K, Jechura J, Neeves K, Sheehan J, Wallace B, Montague L, Slayton A, Lukas J (2002) Lignocellulosic biomass to ethanol process design and economics utilizing cocurrent dilute acid prehydrolysis and enzymatic hydrolysis for corn stover. NREL, Golden, Colorado. In: Proceedings of NREL technical report, pp 510-532

Ahindra N (2008) Biofuels refining and performance. McGraw Hill, USA

Aristidou A, Penttila M (2000) Metabolic engineering applications to renewable resource utilization. Curr Opin Biotechnol 11:187-198

Avci A, Saha BC, Dien BS, Kennedy GJ, Cotta MA (2013) Response surface optimization of corn stover pretreatment using dilute phosphoric acid for enzymatic hydrolysis and ethanol production. Bioresour Technol 130:603-612

Balat M, Balat H, Oz C (2008) Progress in bioethanol processing. Prog Energy Combust Sci 34:551-573

Ballesteros I, Oliva JM, Sanchez F, Ballesteros M (2001) Ethanol production from lignocellulosic byproducts of olive oil extraction. Appl Biochem Biotechnol 91:237-252

Ballesteros I, Oliva JM, Negro MJ, Manzanares P, Ballesteros M (2002) Ethanol production from olive oil extraction residue pretreated with hot water. Appl Biochem Biotechnol 98:717-732 
Ballesteros M, Oliva JM, Negro MJ, Manzanares P, Ballesteros I (2004) Ethanol from lignocellulosic materials by a simultaneous saccharification and fermentation process (SFS) with Kluyveromyces marxianus CECT 10875. Process Biochem 39:1843-1848

Bayer EA, Chanzy H, Lamed R, Shoham Y (1998) Cellulose, cellulases and cellulosomes. Curr Opin Struct Biol 8:548-557

Beguin P, Aubert JP (1994) The biological degradation of cellulose. FEMS Microbiol Rev 13:25-58

Bhatia L, Paliwal S (2011) Ethanol producing potential of Pachysolen tannophilus from sugarcane bagasse. Int $\mathrm{J}$ Biotechnol Bioeng Res 2(2):271-276

Bjerre AB, Olesen AB, Fernqvist T (1996) Pretreatment of wheat straw using combined wet oxidation and alkaline hydrolysis resulting in convertible cellulose and hemicellulose. Biotechnol Bioeng 49:568-577

Bracey D (1998) Determination of the intracellular $\mathrm{pH}(\mathrm{pHi})$ of growing cells of Saccharomyces cerevisiae the effect of reducedexpression of the membrane $\mathrm{H}^{+}$-ATPase. J Microbiol Methods 31:113-124

Brown RC (2003) Proceedings of Biorenewable resources, 1st edn. Iowa State Press, Ames, Iowa

Camacho LM, Dumee L, Zhang J, de Li J, Duke M, Gomez J, Gray S (2013) Advances in membrane distillation for water desalination and purification applications. Water 5:94-196

Carmen MO, Muller Laurindo JB, Yamashita F (2009) Effect of cellulose fibers on the crystallinity and mechanical properties of starch-based films at different relative humidity values. Carbohydr Polym 77(2):293-299

Cassab CI, Varner JE (1988) Cell wall proteins. Ann Rev Plant Physiol 39:321-353

Chang VS, Holtzapple MT (2000) Fundamental factors affecting biomass enzymatic reactivity. Appl Biochem Biotechnol 84-86:5-37

Cheng JJ, Timilsina GR (2011) Status and barriers of advanced biofuel technologies: a review. Renew Energy 36:3541-3549

Chesson A, Forsberg CW (1988) Polysaccharide degradation by rumen microorganisms. In: Hobson (ed) The rumen microbial ecosystem, pp 251-284

Claassen PAM, Contreras AML, Sijtsma L, Weusthuis RA, Van Lier JB, Van Niel EWJ, Stams AJM, de Vries SS, Weusthuis RA (1999) Utilisation of biomass for the supply of energy carriers. Appl Microbiol Biotechnol 52:741-755

Coyle W (2007) The future of biofuels: a global perspective. Amber Waves 5(5). Available online at www.ers.usda.gov/ AmberWaves/November07/Features/Biofuels.htm

Cuzens JC, Miller JR (1997) Acid hydrolysis of bagasse for ethanol production. Renew Energy 10(2):285-290

Dien BS, Cotta MA, Jeffries TW (2003) Bacteria engineered for fuel ethanol production current status. Appl Microbiol Biotechnol 63:258-266

Franks CD, Burow GB, Burke JJ (2006) A comparison of US and Chinese sorghum germplasm for early season cold tolerance. Crop Sci 46:1371-1376

Fulton L, Howes T, Hardy J (2004) Biofuels for transport: an international perspective. International Energy Agency, Paris, France. Available online at http://www.iea.org/textbase/nppd/ free/2004/biofuels2004.pdf

Gamez S, Cabriales JJG, Ramirez JA, Garrote G, Vazquez M (2006) Study of hydrolysis of sugar cane bagasse using phosphoric acid. J Food Eng 74:78-88

Garcia-Kirchner O, Segura-Granados M, Rodriguez-Pascual P (2005) Effect of media composition and growth conditions on production of beta -glucosidase by Aspergillus niger C-6. Appl Biochem Biotechnol 121(1):347-360
Garg SK, Neelakantan S (1982) Effect of nutritional factors on cellulase enzyme and microbial protein production by Aspergillus terreus and its evaluation. Biotechnol Bioeng 24(1):109-125

Goldemberg J, Guardabasi P (2009) Are biofuels a feasible option? Energy Policy 37:10-14

Grous WR, Converse AO, Grethlein HE (1986) Effect of steam explosion pretreatment on pore size and enzymatic hydrolysis of poplar. Enz Microb Technol 8:274-280

Gupte A, Madamwar D (1997) Solid state fermentation of lignocellulosic waste for cellulose and $\beta$-glucosidase production by cocultivation by Aspergillus ellipticus and Aspergillus fumigatus. Biotechnol Prog 13:166-169

Gutierrez-Correa M, Tengerdy RP (1997) Production of cellulase on sugar cane bagasse by fungal mixed culture solid substrate fermentation. Biotechnol Lett 19:665-667

Hadad D, Geresh S, Sivan A (2005) Biodegradation of polyethylene by the thermophilic bacterium Brevibacillus borstelensis. J Appl Microbiol 98(5):1365-2672

Hahn-Hägerdal B, Galbe M, Gorwa-Grauslund MF, Liden G, Zacchi $\mathrm{G}$ (2006) Bio-ethanol: the fuel of tomorrow from the residues of today. Trend. Biotechnol 24(12):549-556

Hamelinck CN, Hooijdonk GV, Faaij APC (2005) Ethanol from lignocellulosic biomass: techno-economic performance in short-, middle- and long-term. Biomass Bioenerg 28:384-410

Heaton EA, Flavell RB, Mascia PN, Thomas SR, Dohleman FG, Long SP (2008) Herbaceous energy crop development: recent progress and future prospects. Curr Opin Biotechnol 19:202-209

Holtzapple MT (1993) Hemicellulose. In: Macrae R, Robinson RK, Sadler MJ (eds) Encyclopedia of food science, food technology and nutrition, vol 2. Academic Press, London, pp 2324-2334

Ingram LO, Doran JB (1995) Conversion of cellulosic materials to ethanol. FEMS Microbiol Rev 16:235-241

Irwin DC, Spezio M, Walker LP, Wilson DB (1993) Studies of eight purified cellulases specificity synergism and binding domain effects. Biotechnol Bioeng 42:1002

Itoh H, Wada M, Honda Y, Kuwahara M, Watanabe T (2003) Bioorganosolve pretreatments for simultaneous saccharification and fermentation of beech wood by ethanolysis and white-rot fungi. J Biotechnol 103(3):273-280

Ivanova V, Petrova P, Hristov J (2011) Application in the ethanol fermentation of immobilized yeast cells in matrix of alginate/ magnetic nanoparticles, on chitosan-magnetite microparticles and cellulose-coated magnetic nanoparticles. Int Rev Chem Eng 3:289-299

Kaar WE, Holtzapple MT (2000) Using lime pretreatment to facilitate the enzymic hydrolysis of corn stover. Biomass Bioenerg 18:189-199

Kansoh AL (1998) Biodegradation and utilization of bagasse with Trichoderma reesei. Polym Degrad Stab 63:273-278

Khiyami MA, Pometto AL, Brown RC (2005) Detoxification of corn stover and corn starch pyrolysis liquors by Pseudomonas putida and Streptomyces setonii suspended cells and plastic compost support biofilms. J Agric Food Chem 53:2978-2987

Kim S, Dale BE (2004) Global potential bioethanol production from wasted crops and crop residues. Biomass Bioenerg 26:361-375

Knauf M, Moniruzzaman M (2004) Lignocellulosic biomass processing: a perspective. Int Sugar J 106:147-150

Koegel RG, Sreenath HK, Straub RJ (1999) Alfalfa fiber as a feedstock for ethanol and organic acids. Appl Biochem Biotechnol 92(6):105-115

Kuhad RC, Singh A (1993) Lignocellulose biotechnology: current and future prospects. Crit Rev Biotechnol 13:151-172

Kuhad RC, Singh A, Ericksson KE (1997) Microorganisms and enzymes involved in the degradation of plant fiber cell walls. Adv Biochem Eng Biotechnol 57:45-125 
Li BZ, Balan V, Yuan YJ, Dale BE (2010) Process optimization to convert forage and sweet sorghum bagasse to ethanol based on ammonia fiber expansion (AFEX) pre-treatment. Bioresour Technol 101:1285-1292

Li DC, Li AN, Papageorgiou AC (2011) Cellulases from Thermophilic fungi: recent insights and biotechnological potential. Enzyme Res. doi:10.4061/2011/308730

Licht FO (2008) World fuel ethanol production. Renewable Fuels Association. http://www.ethanolrfa.org/resource/facts/trade/

Limayema A, Ricke SC (2012) Lignocellulosic biomass for bioethanol production: current perspectives, potential issues and future prospects. Prog Energy Combust Sci 38:449-467

Lynd LR (1996) Overview and evaluation of fuel ethanol from cellulosic biomass: technology, economics, the environment, and policy. Ann Rev Energy Environ 21:403-465

Lynd LR, Weimer PJ, van Zyl WH, Pretorius IS (2002) Microbial cellulose utilization: fundamentals and biotechnology. Microbiol Mol Biol Rev 66(3):506-577

Lynd LR, van Zyl WH, Mcbride JE, Laser M (2005) Consolidated bioprocessing of cellulosic biomass: an update. Curr Opin Biotechnol 16(5):577-583

Mandels M, Weber J (1969) Production of cellulases. Adv Chem Series 95:391-414

Mooney CA, Mansfield SD, Touhy MG, Saddler JN (1998) The effect of initial pore volume and lignin content on the enzymatic hydrolysis of softwoods. Bioresour Technol 64:113-119

Mosier N, Wyman C, Dale B, Elander R, Lee YY, Holtzapple M, Ladisch M (2005) Features of promising technologies for pretreatment of lignocellulosic biomass. Bioresour Technol 96(6):673-686

Neves MA, Kimura T, Shimizu N, Nakajima M (2007) State of the art and future trends of bioethanol production, dynamic biochemistry, process biotechnology and molecular biology. In: Proceedings of global science books, pp 1-13

Niehaus F, Bertoldo C, Kahler M, Antranikian G (1999) Extremophiles as a source of novel enzymes for industrial application. Appl Microbiol Biotechnol 51:711-729

Nieves RA, Ehrman CI, Adney WS, Elander RT, Himmel ME (1998) Technical communication: survey and analysis of commercial cellulase preparations suitable for biomass conversion to ethanol. World J Microbiol Biotechnol 14:301-304

Pan XJ, Arato C, Gilkes N, Gregg D, Mabee W, Pye K, Xiao ZZ, Zhang X, Saddler J (2005) Biorefining of softwoods using ethanol organosolv pulping: preliminary evaluation of process streams for manufacture of fuel-grade ethanol and co-products. Biotechnol Bioeng 90(4):473-481

Perlack RD, Wright L, Turhollow LA, Graham RL, Stokes B, Erbach DC (2005) Biomass as feedstock for a bioenergy and bioproducts industry: the technical feasibility of a billion-ton annual supply. In: Proceedings of Oak Ridge National Laboratory Report ORNL/TM-2005/66. US Department of Energy, Oak Ridge, TN

Pocas-Fonseca MJ, Maranhac AQ (2005) Diversity among Cellulolytic Fungi. In: Satyanarayan T, Johri BN (eds) Microbial diversity: current perspectives and potential applications. I. K. International Pvt. Ltd., New Delhi (India), pp 165-180

Ramos DF, Fontana J (1996) Pretreatment of sugarcane bagasse for enhanced ruminal digestion. Appl Biochem Biotech 57:171-182

Rashid MH, Siddiqui KS (1998) Thermodynamic and kinetic study of stability of the native and chemically modified $\beta$-glucosidase from Aspergillus niger. Process Biochem 33(2):109-115

Ravindranath NH, Lakshmi CS, Manuvie R, Balachandra P (2011) Biofuel production and implications for land use, food production and environment in India. Energy Policy 39:5737-5745

Reddy N, Yang Y (2005) Biofibers from agricultural byproducts for industrial applications. Trend Biotechnol 23:22-27
Reese ET (1976) History of the cellulase program at the US Army Natick Development Center. Biotechnol Bioeng Symp 9:451-467

RFA (2010) Ethanol industry outlook: climate of opportunity. http:// www.ethanolrfa.org/page/-/objects/pdf/outlook/RFAoutlook2010_ fin.pdf?nocdn $=1$

Saha BC, Cotta MA (2008) Lime pretreatment, enzymatic saccharification and fermentation of rice hulls to ethanol. Biomass Bioenerg 32:971-977

Saini JK, Anurag RK, Arya A, Kumbhar BK, Tewari L (2013) Optimization of saccharification of sweet sorghum bagasse using response surface methodology. Ind Crop Prod 44:211-219

Samir MASA, Alloin F, Dufresne A (2005) Review of recent research into cellulosic whiskers, their properties and their application in nanocomposite field. Biomacromolecules 6:612-626

Sanchez OJ, Cardona CA (2008) Trends in biotechnological production of fuel ethanol from different feedstocks. Bioresour Technol 99:5270-5295

Sarkar N, Ghosh SK, Bannerjee S, Aikat K (2012) Bioethanol production from agricultural wastes: an overview. Renew Energy 37:19-27

Sasikumar E, Viruthagiri T (2008) Optimization of process conditions using response surface methodology (RSM) for ethanol production from pretreated sugarcane bagasse: kinetics and modeling. BioEnergy Res 1(3-4):239-247

Singh A, Bishnoi NR (2012) Enzymatic hydrolysis optimization of microwave alkali pretreated wheat straw and ethanol production by yeast. Bioresour Technol 108:94-101

Sipos B, Reczey J, Somorai Z, Kadar Z, Dienes D, Reczey K (2009) Sweet sorghum as feedstock for ethanol production: enzymatic hydrolysis of steam-pretreated bagasse. Appl Biochem Biotechnol 153:151-162

Soderstrom J, Galbe M, Zacchi G (2005) Separate versus simultaneous saccharification and fermentation of two-step steam pretreated softwood for ethanol production. J Wood Chem Technol 25(3):187-202

Stahlberg J, Johansson G, Pettersson G (1988) A binding-sitedeficient, catalytically active, core protein of endoglucanase III from the culture filtrate of Trichoderma reesei. Eur J Biochem 173:179-183

Subramanian KA, Singal SK, Saxena M, Singhal S (2005) Utilization of liquid biofuels in automotive diesel engines: an Indian perspective. Biomass Bioenerg 29:65-72

Sun Y, Cheng J (2002) Hydrolysis of lignocellulosic materials for ethanol production: a review. Bioresour Technol 83(1):1-11

Talebnia F, Karakashev D, Angelidaki I (2010) Production of bioethanol from wheat straw: an overview on pretreatment, hydrolysis and fermentation. Bioresour Technol 101(13):4744-4753

Tolan J (2002) Iogen's process for producing ethanol from cellulosic biomass. Clean Technol Enviro Policy 3:339

Tomaz CT, Queiroz JA (1999) Studies on the chromatographic fractionation of Trichoderma reesei cellulases by hydrophobic interaction. J Chromatogr A 865(1-2):123-128

Tucker MP, Kim KH, Newman MM, Nguyen QA (2003) Effects of temperature and moisture on dilute-acid steam explosion pretreatment of corn stover and cellulase enzyme digestibility. Appl Biochem Biotechnol 10:105-108

US Department of Energy Biomass Program (2009). http://www.eere. energy.gov/biomass/pdfs/biomass_deep_dive_pir.pdf

Volke-Spulveda T (1998) Microbial degradation of thermo- oxidized low-density polythene. J Appl Polym Sci 79:1435-1440

Wood TM, McCrae SI (1979) Synergism between enzymes involved in the solubilization of native cellulose. Adv Chem Ser 181:181

Wooley R, Ruth M, Sheehan J, Ibsen K, Majdeski H, Galvez A (1999) Lignocellulosic biomass to ethanol process design and economics utilizing co-current dilute acid prehydrolysis and 
enzymatic hydrolysis. In: Proceedings of current and futuristic scenarios. Technical report NREL/TP-580-26157. Golden, CO (USA), National Renewable Energy Laboratory, p 123

Wright JD (1988) Ethanol from lignocellulosics: an overview. Energy Prog 84:71-80

Wyman CE, Hinman ND (1990) Ethanol: fundamentals of production from renewable feedstocks and use as transportation fuel. Appl Biochem Biotechnol 24:735-775
Wyman C, Dale B, Elander R, Holtzapple M, Ladish M, Lee Y (2005a) Comparative sugar recovery data from laboratory scale application of leading pretreatment technologies to corn stover. Bioresour Technol 96(18):2026-2032

Wyman C, Dale B, Elander R, Holtzapple M, Ladish M, Lee YY (2005b) Coordinated development of leading biomass pretreatment technologies. Bioresour Technol 96(18):1959-1966 